\title{
Pemberdayaan Pendidikan bagi Masyarakat Melalui Program KKN DR 31 di Desa Kota Datar Hamparan Perak Deli Serdang Tahun 2021
}

\author{
Iqbal A. Muin ${ }^{*}$, Nafa Zhafirah², Afifah Husnaini ${ }^{3}$, Nur Hanifah", Lestarina \\ Matondang $^{5}$, Reviza Ikhwilda Windari ${ }^{6}$, Risky Wulandari ${ }^{7}$ \\ ${ }^{1}$ Universitas Islam Negeri Sumatera Utara Medan, Indonesia \\ ${ }^{2}$ Universitas Islam Negeri Sumatera Utara Medan, Indonesia \\ ${ }^{3}$ Universitas Islam Negeri Sumatera Utara Medan, Indonesia \\ ${ }^{4}$ Universitas Islam Negeri Sumatera Utara Medan, Indonesia \\ ${ }^{5}$ Universitas Islam Negeri Sumatera Utara Medan, Indonesia \\ ${ }^{6}$ Universitas Islam Negeri Sumatera Utara Medan, Indonesia \\ ${ }^{7}$ Universitas Islam Negeri Sumatera Utara Medan, Indonesia \\ * Corresponding Author. E-mail: ${ }^{\text {ibnati02@gmail.com }}$
}

Receive: $15 / 07 / 2021$

Accepted: $30 / 08 / 2021$

Published: 01/10/2021

\begin{abstract}
Abstrak
Kuliah Kerja Nyata saat pandemi covid-19 seperti ini berbeda dengan KKN pada umumnya. KKN DR pada saat pandemi covid-19 membagi lagi dalam beberapa kelompok untuk terjun langsung kelapangan. Dengan adanya KKN DR di tengah pandemi covid-19 diharapkan Mahasiswa tetap memiliki urgensi pengabdian sehingga dapat mengembangkan kompetensi Mahasiswa dan interaksi dalam bersosial di masyarakat. Penelitian ini bertujuan untuk mengetahui peran Kuliah Kerja Nyata sebagai wujud pengabdian kepada masyarakat. Populasi dan Sampel pada penelitian ini adalah kelompok 31 KKN DR UINSU dengan Metode pengumpulan data, observasi serta dokumentasi. Dengan menggunakan tema sosial kemasyarakatan, keagamaan, kesehatan masyarakat, sains dan teknologi. Hasil pada penelitian ini menunjukkan bahwa kegiatan KKN DR UINSU sebagai wujud pengabdian kepada masyarakat pada masa pandemi masih tetap bisa dirasakan manfaatnya oleh masyarakat dan peran mahasiswa masih bisa dilakukan dengan rangkaian kegiatan inovatif serta tetap menjalankan protokol kesehatan.
\end{abstract}

Kata Kunci: Sosial, Kemasyarakatan, Keagamaan, Pemberdayaan Pendidikan.

\section{Empowerment of Education for the Community Through the DR 31 KKN Program in the Village of Kota Datar, Overlay Perak, Deli Serdang in 2021}

\begin{abstract}
Real Work Lectures during the covid-19 pandemic are different from KKN in general. DR's $K K N$ during the covid-19 pandemic divided into several groups to go directly to the field. With the DR KKN in the midst of the covid-19 pandemic, it is hoped that students will still have the urgency of service so that they can develop student competencies and social interactions in the community. This study aims to determine the role of Real Work Lectures as a form of community service. The population and sample in this study were a group of $31 \mathrm{KKN} D R$ UINSU with data collection, observation and documentation methods. By using social, religious, public health, science and technology themes. The results of this study indicate that
\end{abstract}


the community service activities of DR UINSU as a form of community service during the pandemic can still be felt by the community and the role of students can still be carried out with a series of innovative activities and continue to carry out health protocols.

Keywords: Social, Community, Religious, Education Empowerment.

\section{Pendahuluan}

Kuliah Kerja Nyata $(\mathrm{KKN})$ merupakan salah satu bentuk pendidikan yang menjadikan mahasiswa mendapatkan pengalaman yang berada di luar kampus dan lebih tepatnya ditengah-tengah kehidupan masyarakat.

Kuliah Kerja Nyata yang dilakukan di luar kampus maksudnya ialah untuk menumbuhkan hubungan pendidikan tinggi dengan perkembangan dan kebutuhan masyarakat akan Ilmu pengetahuan. Kuliah Kerja Nyata $(\mathrm{KKN})$ dilaksanakan di lokasi yang melibatkan masyarakat sehingga timbulnya realisasi serta dapat memberikan manfaat bagi masyarakat.

Secara sederhana, Kuliah Kerja Nyata (KKN) dilaksanakan secara langsung dan bertempat tinggal di lokasi dalam jangka waktu yang ditentukan. Namun, pada tahun ini kegiatan KKN dilaksanakan secara langsung namun tidak untuk bertempat tinggal di lokasi. Peraturan ini dibuat untuk memutuskan rantai penyebaran Covid-19. Jadi, peserta KKN dapat melakukan kegiatan secara langsung dan pulang kerumah atau disebut KKN-DR (Kuliah Kerja Nyata Dari Rumah dan Terukur).

Kuliah Kerja Nyata (KKN) juga merupakan kegiatan Intrakulikuler yang menggabungkan pelaksanaan Tri Dharma Perguruan Tinggi dengan metode yang menjadikan mahasiswa mendapatkan pengalaman belajar serta bekerja terutama dalam hal kegiatan pemberdayaan Masyarakat. Pemberdayaan Masyarakat adalah salah satu bentuk kegiatan yang berkaitan erat dengan upaya penanggulangan masalah-masalah yang terkait. Menurut (Mas'oed, 1990) Pemberdayaan masyarakat merupakan suatu upaya untuk memberikan kemampuan atau penggalangan kepada masyarakat.

\begin{abstract}
Pemberdayaan Masyarakat adalah sebagai strategi tercepat dalam pembangunan yang telah berkembang dalam berbagai pemikiran walau pada hasil kenyataannya belum maksimal. Pemberdayaan Masyarakat merupakan suatu hal yang sering dibicarakan oleh Masyarakat terkait dengan perubahan yang terjadi, terutama sering dikaitkan dengan kemampuan masyarakat yang masih kurang.

Jadi, dalam penelitian ini membahas bagaimana pemberdayaan masyarakat melalui program KKN-DR di Desa Kota Datar, Hamparan Perak, Deli Serdang yang bertema Sosial Kemasyarakatan, Keagamaan, Kesehatan Masyarakat, Sains dan Teknologi.
\end{abstract}

\section{Metode}

Dalam penelitian ini, peneliti menggunakan metode kualitatif dengan cara mengumpulkan data untuk mengetahui hasil. Menurut Gunawan (2013: 80) penelitian kualitatif bertujuan untuk mengembangkan masalah yang dihadapi, menjelaskan kebenaran mengenai teori serta mengembangkan pemahaman terhadap fenomena.

Penelitian kualitatif sifatnya deskriptif analitik. Data yang diperoleh dari penelitian ini seperti hasil pengamatan, hasil pemotretan, hasil wawancara, analisis dokumen, catatan lapangan, disusun dilokasi penelitian dan tidak dibuat dalam bentuk angka. Dalam penelitian ini, berada pada bentuk proses bukan pada bentuk hasil. Penelitian ini dilakukan di Desa Kota Datar, Hamparan Perak, Deli Serdang pada tanggal 10 Juli 2021- 10 Agustus 2021.

Pelaksanaan program pemberdayaan masyarat di desa Kota Datar, Hamparan 
Perak, Deli Serdang terbagi dalam lima bidang yakni bidang sosial kemasyarakatan, keagamaan dan keislaman, kesehatan masyarakat, sains dan teknologi, dan bidang moderasi beragama dan kerukunan ummat beragama.

\section{Hasil dan Pembahasan}

\section{A. Sosial Kemasyarakatan}

Kegiatan sosial kemasyarakatan adalah kegiatan yang dilakukan dengan anggota masyarakat di lingkungan tempat tinggal. Partisipasi dalam kegiatan sosial kemasyarakatan mengacu pada partisipasi seseorang dalam kegiatan sosial kemasyarakatan yang ada di lingkungan tempat tinggal. Dengan diadakannya bidang sosial kemasyarakatan ini, peserta KKN DR UINSU kelompok 31 tahun 2021 membantu masyarakat di Desa Kota Datar di antaranya yaitu:

\section{Sosialiasi ke Masyarakat}

Proses penyebaran kebudayaan kepada warga masyarakat baru disebut sosialisasi. Sosialisasi ditentukan oleh lingkungan sosial, ekonomi dan budaya tempat individu tersebut menetap, selanjutnya ditentukan interaksi pengalaman dan kepribadiannya. Tujuan sosialisasi adalah agar peserta KKN-DR UINSU kelompok 31 tahun 2021 dapat beradaptasi dengan norma sosial yang berperan di desa Kota Datar, Hamparan perak, dapat diterima menjadi anggota masyarakat dan agar dapat terjalinnya silaturahmi antara masyarakat dan peserta KKN. Hasilnya masyarakat dapat menerima peserta KKN dengan baik dan menyetujui program kerja yang akan dilaksanakan. Kegiatan tersebut dilakukan sesuai dengan protokol kesehatan. Kegiatan ini dilakukan peserta KKN bersama dengan kepala desa dan masyarakat desa pada tanggal 15 Juli 2021. Dapat dilihat pada gambar 1:

Gambar 1. Sosialisasi dengan kepala desa dan masyarakat
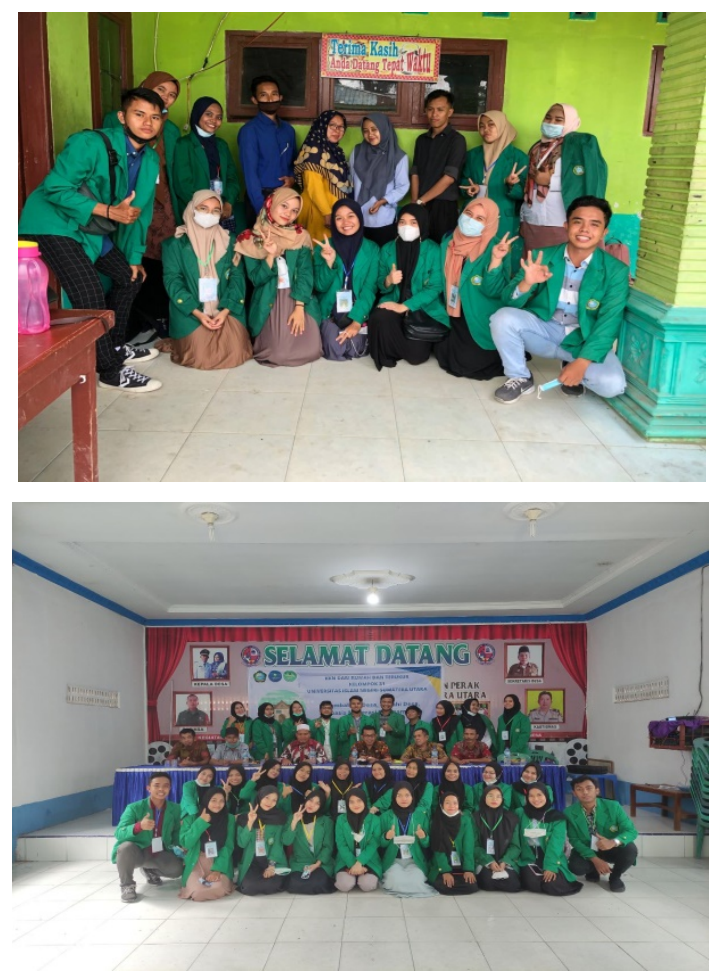

\section{Gotong-royong}

Gotong royong merupakan budaya yang dikembangkan sebagai warisan dalam berkembang dalam kehidupan sosial masyarakat Indonesia secara turun menurun. Gotong royong adalah suatu pekerjan yang dilakukan bersama, perjuangan bantu membantu. Dalam gotong royong terkandung nilai-nilai sosial yang diperlukan untuk kemajuan masyarakat. Kegiatan gotong royong di desa Kota Datar, Hamparan perak dikerjakan setiap hari Jum'at. Ditujukan untuk bersama-sama membersihkan jalan, selokan, mengecat tembok merapikan tanaman dan membersihkan musholla Al-Ikhlas desa Kota Datar, Dusun XII, Hamparan Perak. Hasilnya kebersihan lingkungan dan musholla menjadi meningkat sehingga tercipta kenyamanan masyarakat dan musholla yang bersih untuk dipakai beribadah. Kegiatan dilaksanakan tetap mematuhi protokol kesehatan. Kegiatan ini dilakukan bersama dengan masyarakat desa pada tanggal 16, 23 dan 30 Juli 2021. Dapat dilihat pada Gambar 2.

Gambar 2. Kegiatan gotong royong 

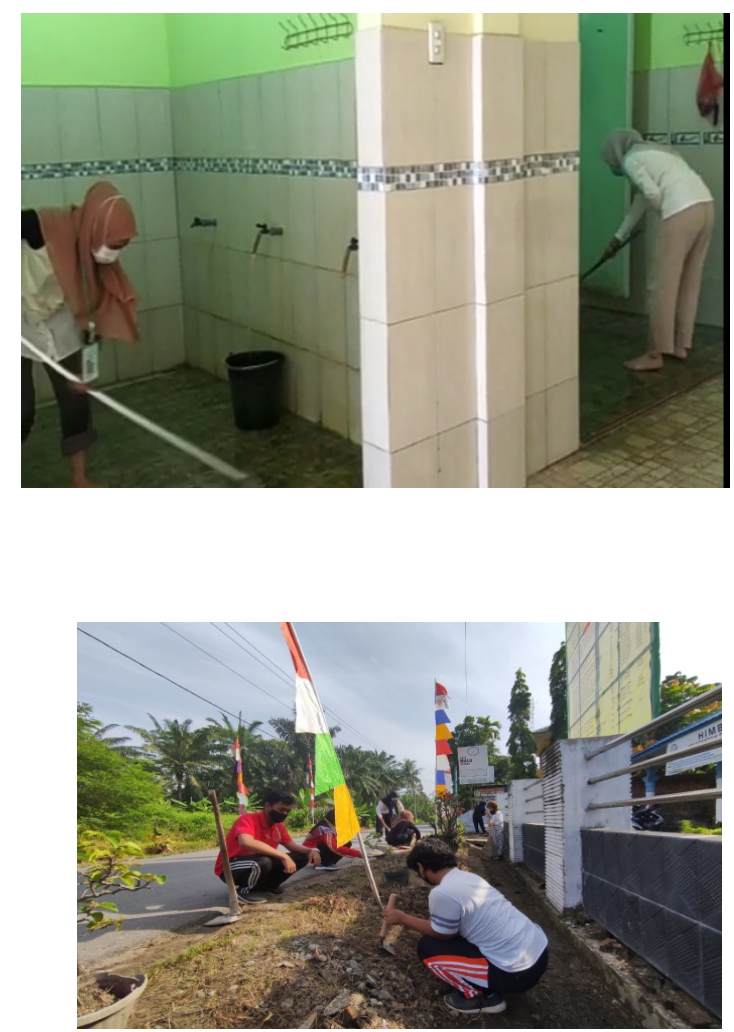

3. Sosialisasi bersama anak-anak SD dan MA

Masa pandemi masih berlangsung sampai tahun 2021 ini. Walau masih berada di masa pandemi, MAS Ar-rahman di desa Kota Datar, Hamparan Perak sudah mulai membuka sekolah walaupun hanya dua jam saja yaitu dimulai jam 8.00-10.00 WIB. Ini dilakukan karena pihak sekolah dan guru merasa tidak dapat mencapai target pembelajaran jika tetap melaksanakan Pembelajaran Jarak Jauh (PJJ).

Kegiatan sosialisasi anak MA dilaksanakan untuk membuka wawasan kepada peserta didik tentang bagaimana tetap semangat belajar walaupun di masa pandemi. Kegiatan dilakukan sesuai protokol kesehatan. Kegiatan ini dilaksanakan bersamaan dengan mengajak anak-anak SD untuk menonton bersama tentang cerita nabi. Dengan kegiatan ini kami mengharapkan agar anak-anak Desa Kota Datar menambah ilmu pengetahuan dan ingin menumbuhkan semangat belajar anak-anak. Kegiatan ini dilaksanakan pada tanggal 19 Juli 2021. Terlampir pada gambar berikut:
Gambar 3. Kegiatan Sosialisasi Bersama Peserta Didik.

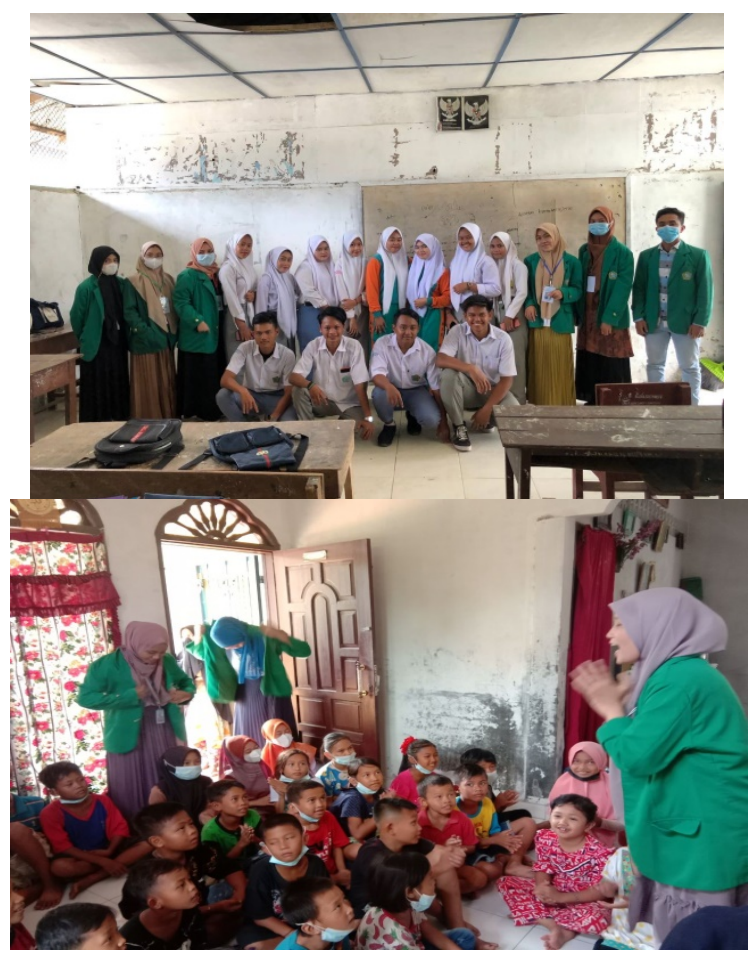

\section{Dekorasi Ruang Belajar dan Pemberian buku}

Ruang belajar harus dibuat dengan ideal agar anak-anak merasa nyaman dan tenang saat ditempati untuk belajar. Peserta KKN memanfaatkan dinding MDA yang kurang terurus dengan menambahkan gambar huruf-huruf hijaiyah dan kalimat tahayyibah. Kami juga menghias meja dan memperbaiki beberapa meja yang tidak layak pakai.

Selain itu, kami juga membuka pojok literasi dengan menyumbangkan beberapa buku untuk anak-anak di MDA tersebut. Pemberian buku ini merupakan donasi dari setiap peserta KKN, kami sepakat untuk memberi 2 buku/orang agar dapat didonasikan ke MDA. Buku yang kami berikan sebanyak 60 buah, yaitu buku pengetahuan, sejarah tentang nabi, cerita anak, cerita mengenai sahabat dan lainnya. Buku-buku tersebut kami susun di pojok literasi di MDA Kota Datar, Hamparan Perak. Hasilnya ruang belajar dan dinding kelas menjadi terlihat lebih baik dan rapi. Kegiatan ini kami laksanakan pada tanggal 
7 Agustus 2021. Terlampir pada gambar berikut:

Gambar 4. Dekorasi Ruang Belajar.

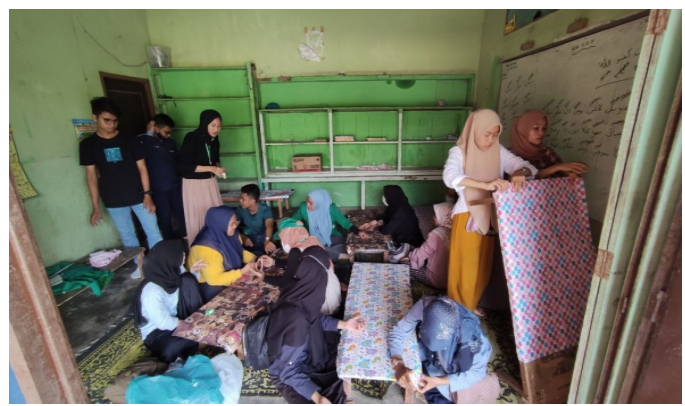

\section{B. Keagamaan}

Program kerja yang dilaksanakan dengan beberapa aspek yaitu, sosial kemasyarakatan, keagamaan, kesehatan masyarakat, sains dan teknologi. Kelima aspek ini dilakukan untuk memenuhi pelaksanaan Kuliah Kerja Nyata DariRumah Universitas Islam Negeri Sumatera Utara yang dilaksanakan selama 30 hari, tehitung sejak pembukaan pada tanggal 10 Juli 2021 sampai dengan penutupan pada tanggal 12 Agustus 2021.

Bidang keagamaan merupakan sebuah kewajiban UINSU sebagai Perguruan tinggi Islam yang pembelajaran nya berpedoman kepada Al-Quran dan AsSunnah Nabi Muhammad SAW. Sebagai bentuk pemberdayaan kepada masyarakat dalam bidang keagamaan, peserta KKN DR UINSU kelompok 31 tahun 2021 melaksanakan pengedukasian dan pendampingan dengan program yang telah direncanakan. Antara lain:

\section{Mengajar dan Pembinaan Anak Berbasis Keislaman}

Pada masa anak usia sekitaran umur 512 tahun adalah pada tahap ini anak-anak usia seperti ini berkembang dengan baik, dimana harus memberikan hal yang positif akan berdampak positif juga bagi anak didik. Salah satu cara untuk menyelamatkan generasi muda dengan cara memberikan serta menanamkan nilai-nilai ke Islaman, oleh karena itu mahasiswa KKN DR
UINSU bersama masyarakat desa sekitar bekerja sama dalam membina dan juga mengajar anak didik pada tangal 19 Juli 2021. Terlampir pada gambar berikut.

Gambar 5. Kegiatan mengajar dan pembinaan anak berbasis keislaman.

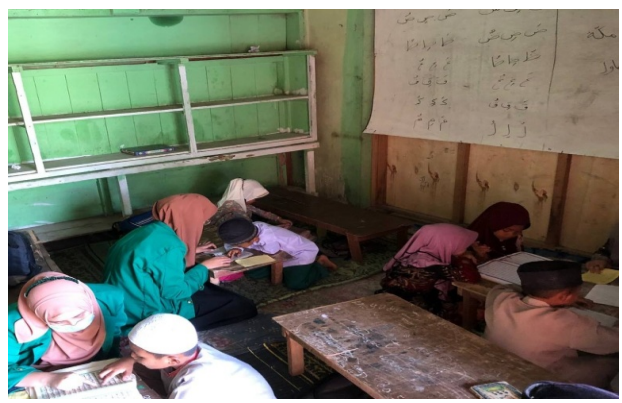

Pada anak usia 0-12 tahun berada pada jenjang pendidikan anak usia dini dan pendidikan dasar. Pada tahap ini anak merupakan individu yang berbeda, unik, dan memiliki karakteristik tersendiri sesuai dengan tahapan usianya. Kegiatan ini dilakukan dengan mengajar ngaji, belajar bahasa Arab, mengenal huruf-huruf hijaiyah, menanamkan nilai-nilai keislaman didalam diri dan juga hatinya, dan juga menjadikan unsur keagamaan didalam kehidupan sehari-hari seperti (kejujuran, sopan santun, dan lain sebagainya).

Tujuan dari kegiatan ini berkontribusi dalam pengetahuan pada anak. Jadi, dapat disimpulkan bahwa nilai-nilai keagaaman yang ada pada diri seseorang merupakan tingkah laku yang didapat seseorang dalam kehidupan dan seberapa besar seseorang itu meyakini kehidupan beragama terhadap dirinya dan kehidupan nya (Ratna Wati, 2016).

\section{Pelaksanaan kegiatan sosial keagamaan (Wirid)}

Kegiatan ini dilakukan bersama dengan masyarakat desa sekitar pada tanggal 31 Juli 2021 yang dilakukan dirumah salah satu rumah warga desa tersebut. Pada kegiatan ini menjadi suatu kegiatan rutin yang dilakukan oleh masyarakat setempat untuk tetap memiliki nilai-nilai keislaman dan juga menerapkannya. Terlampir pada gambar berikut: 
Gambar 6 kegiatan sosial keagamaan (wirid).

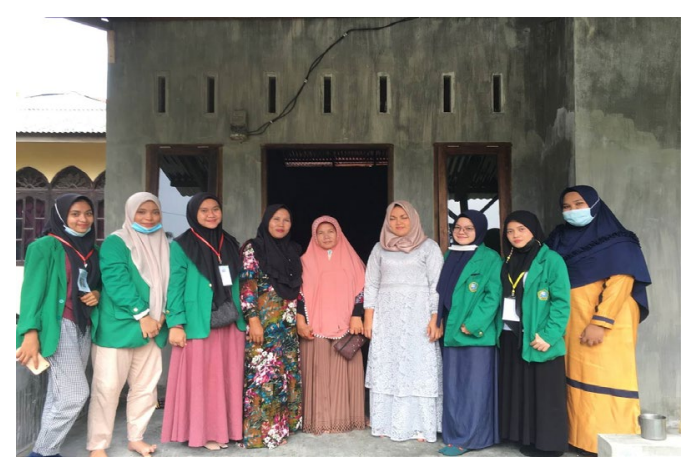

Kegiatan wirid dilakukan 1 kali dalam seminggu betepatan pada setiap hari jumat. Secara teoritis menurut (Iswandi, 2019) Pendidikan sebagai bagian utama dalam pengembangan norma-norma dan nilai-nilai kepada Masyarakat. Melalui pendidikan, seseorang akan mendapatkan pemahaman serta kompetensi dalam bermasyarakat yang semakin terjalin. Tujuan kegiatan tersebut untuk bisa memperkuat dan juga membangun hubungan yang sehat terhadap masyarakat desa tersebut.

\section{Pendampingan Bakat Anak Berbasis Keislaman}

Bakat setiap anak berbeda-beda mulai dari bidang olahraga, seni, keagamaan, teknolisi dan lain sebagainnya. Selain itu, setiap anak memiliki minat terhadap bidang yang dikuasainya. Dengan minat tersebut dapat menunjang bakat yang dimilikinya. Kegiatan ini dilakukan untuk memperkuat bakat dan minat anak-anak dalam bidang keagamaan. Oleh karena itu, mahasiswa KKN DR UINSU melakukan perlombaan yang diikutin oleh anak didik mulai dari TK sampai dengan SMP yang dilakukan pada tanggal 06 Agustus 2021.

Melakukan perlombaan yang berbasiskan keislaman untuk melatih mental anak dalam meningkatkan potensi yang dimiliki oleh anak. Perlombaan yang dilangsungkan antara lain lomba mewarnai, adzan, surah pendek dan juga fashion show. Kegiatan ini dilakukan di kawasan masjid sekitar. Penggunaan mesjid yang dijadikan sebagai pusat perlombaan bertujuan untuk tetap menjadikan mesjid sebagai suatu institusi yang bukan hanya dikenal sebagai tempat berkumpulnya sekelompok masyarakat, akan tetapi dapat menjadikan suatu tempat untuk melakukan aktivitas kebaikan (Kurniawan, 2014). Kegiatan ini juga bertujuan untuk memperingati 1 Muharam $1443 \mathrm{H}$.

\section{Kesehatan Masyarakat}

Kesehatan merupakan Suatu hak asasi manusia yang dijelaskan pada UUD1945, pasal $28 \mathrm{H}$ ayat 1 dan UU No. 23 Tahun 1992 dan sekaligus sebagai investasi setiap warga indonesia, sehingga perlu diupayakan, diperjuangkan, dan tingkatkan pada setiap individu dan seluruh warga bangsa negara agar masyarakat dapat menikmati hidup sehat, dan dapat mewujudkan derajat kesehatan masyarakat yang optimal.

Pemberdayaan kesehatan masyarakat desa merupakan kegiatan swadaya masyarakat yang bertujuan memberdayakan kualitas kesehatan masyarakat untuk melidungi kondisi tubuh dengan perbaharuan status kesehatan dan gizi. Keberhasilan dengan terlaksanannya pemberdayaan kesehatan masyarakat akan bermanfaat untuk memberdayakan dalam meningkatkan kesehatan masyarakat di seluruh masyarakat. Dalam hal ini peran dalam kesehatan masyarakat adalah peran berbagi masker dan Pos Pelayanan Terpandu (posyandu) yang secara langsung berhadapan dengan berbagai permasalahan kemasyarakatan termasuk masalah kesehatan yang dihadapai oleh masyarakat.

\section{Pelaksanaan Program Kegiatan} Peserta KKN-DR Kelompok 31dalam melaksanakan pemberdayaan masyarakat di Desa Kota Datar di bidang kesehatan masyarakat dengan melakukan program kerja yang bermanfaat untuk masyarakat di 
Desa Kota Datar Hamparan Perak. Dengan terselenggaranya program kerja pada bidang kesehatan masyarakat, maka kegiatan yang dilaksanakan peserta $\mathrm{KKN}$ DR Kelompok 31 pada bidang kesehatan masyarakat diantaranya sebagai berikut:

\section{Berbagi Masker Ke Masyarakat Dalam Pencengahan Penyakit COVID-19 pada Desa Kota Datar.}

Pelaksanaan program kegiatan berbagi masker ke masyarakat sekitar desa kota datar yang dilaksanakan pada hari sabtu, 24 Juli 2021 bertempat di desa kota datar pada masyarakat dusun XII dan di depan kantor kepala desa. Dalam terlaksananya kegiatan Berbagi masker pada masyarakat maka akan adanya kesadaran dalam pemberdayaan masyarakat untuk kesehatan tubuh masing-masing.

Sekarang ini Covid-19 menjadi permasalahan dunia yang cukup serius dengan jumlah kasus yang terkena penyakit covid-19 yang selalu mengalami peningkatan setiap harinya. Melakukan sosialisasi ke masyarakat resiko penyakit Covid-19 dan pemberdayaan masyarakat untuk meningkatkan pengetahuan masyarakat. Rendahnya pengetahuan masyarakat di desa kota datar tentang pencegahan Covid-19 baik pada orang lansia, orang dewasa maupun anak- anak di desa tersebut. Tindakan pencegahan merupakan kunci penerapan di pelayanan kesehatan dan masyarakat. Langkah yang harus di lakukan untuk Pencegahan penyakit di masyarakat yaitu dengan mematuhi protokol kesehatan dengan kita selalu menjaga kebersihan tangan menggunakan hand sanitizer, Menjaga jarak (minimal 1 meter), dan Memakai masker.

Penelitian ini menunjukkan bahwa kesadaran pengetahuan masyarakat di desa kota datar mengenai pencegahan Covid-19 masih rendah. Maka perlu ditindak lanjutin dan dilakukan penelitian berbagai media pendidikan kesehatan untuk meningkatkan pengetahuan masyarakat tentang pencengahan Covid-19. Terlampir pada gambar berikut.

Gambar 7. Berbagi Masker dalam

Pencengahan Penyakit Covid-19 pada

Masyarakat desa kota datar.

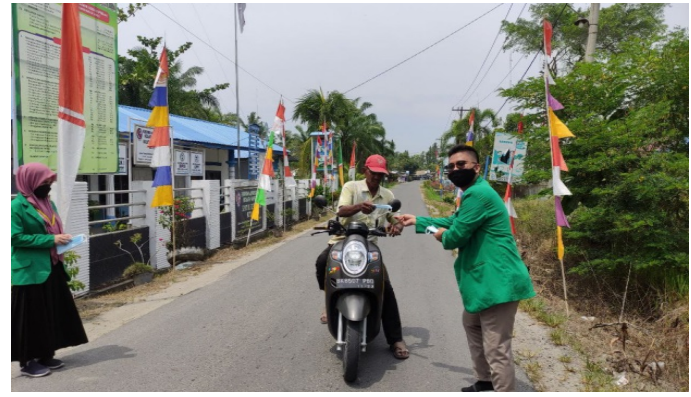

2. Kegiatan Pos Pelayanan Terpandu (Posyandu) di Desa Kota Datar Kec. Hamparan Perak.

Pelaksanaan Program Pemberdayaan masyarakat di Desa Kota Datar pada bidang kesehatan masyarakat yakni melaksanakan Pos Pelayanan Terpandu (Posyandu). Waktu Kegiatan dilaksanankan pada Senin, 02 Agustus 2021 yang lokasi posyandu di dusun IV desa kota datar kecamatan Hamaparan Perak. Adapun kegiatan yang terselenggarakan pada program kerja KKN-DR 31 melaksanakan Posyandu diantaranya yaitu :

1. Pemberian Vitamin A Pada Anak Usia 0- 9 Bulan

Vitamin A merupakan salah satu zat gizi yang termasuk golongan vitamin yang sangat penting dalam menjaga kesehatan tubuh yang berguna untuk kesehatan mata (agar dapat melihat dengan baik) dan untuk kesehatan tubuh (memepertahankan sistem kekebalan tubuh untuk melawan penyakit seperti campak, diare dan penyakit infeksi lain). Cakupan pemberian vitamin $\mathrm{A}$ pada anak di desa kota datar mengalami peningkatan sebesar $70,5 \%$ pada bulan agustus. Di desa kota datar pemberian vitamin A diberikan dalam rangka mencengah kebutaan pada anak, dengan pemberian vitamin A ini dilakukan pada setiap bulan Februari dan Agustus, dengan rentang pemberian vitamin $\mathrm{A}$ ini 
pada anak usia 659 bulan. Dinas Kesehatan Kabupaten Deli Serdang menargetkan balita usia 0- 9 bulan mendapatkan vitamin A, dengan cara para ibu membawa anak balita ke posyandu.

Hasil penelitian bahwa target Bulan Penimbangan Bayi (BPB) pada angka pencapaian pada tahun 2021 di desa kota datar kecamatan hamparan perak hasilnya masih rendah $(82,21 \%)$, hal ini ternyata tidak sesuai dengan target cakupan pemberian vitamin A pada balita yang seharusnya seluruh balita (100\%) sudah mendapatkan vitamin A (Bidan kota Datar).

Gambar 8. Pemberian Vitamin A pada balita di posyandu dusun IV

Desa Kota datar.

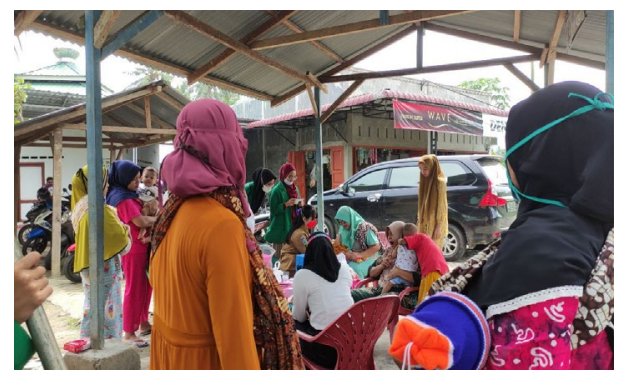

2. Monitoring Berat Badan dan Tinggi Badan Bayi Pada Anak Balita.

Pada kegitan monitoring pertumbuhan pada anak di dominasi oleh berat badan dan tinggi badan anak. Pada anak usia 0-12 bulan didesa kota datar ini penimbangan bayi sangat diperlukan untuk mengetahui pertumbuhan pada anak. Setiap anak ke posyandu akan ada penimbangan berat badan pada anak agar dapat diketahui kondisi berat badan anak tiap bulan.

Selain menimbang berat badan pada anak mengamati pertumbuhan besar lingkar kepala anak bayi seringkali diabaikan oleh para ibu di desa kota datar, padahal pengukuran besar lingkar kepala sangat penting untuk mendeteksi sejak dini gangguan pertumbuhan otak. Pertumbuhan lingkar kepala yang lebih dari normal dapat menandakan adanya hidrosefalus, hematoma subdural atau efusi, sedangkan pertumbuhan lingkar kepala di bawah normal dapat mengakibatkan mikrosefal yang bisa menyebabkan gangguan berhubungan dengan psikomotor dan kognitif. Jika pengukuran tunggal hasilnya berada di luar garis normal. Terlampir pada gambar berikut:

Gambar 9. Penimbangan berat badan dan pengukuran lingkar kepala.
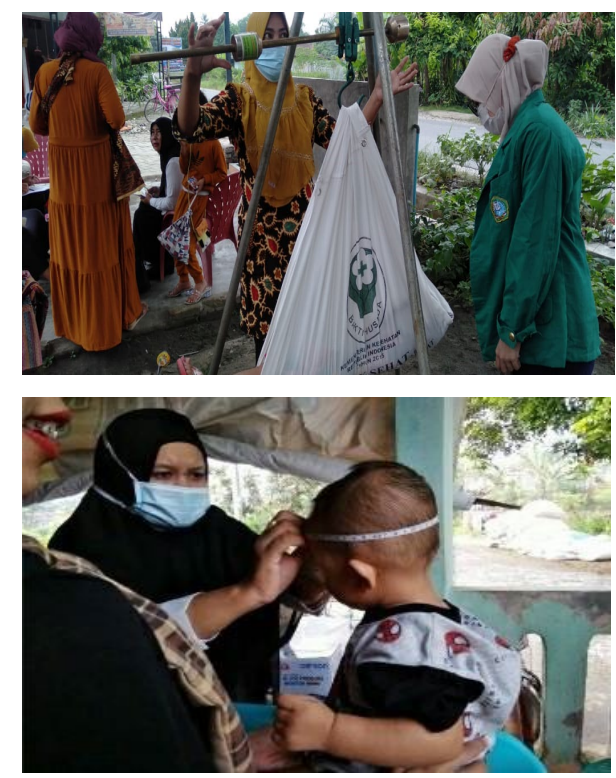

\section{Sains dan Teknologi}

Sains (ilmu pengetahuan) adalah usaha manusia untuk memahami fenomena dan fakta alam, yang kemudian dilestarikan secara konseptual dan sistematis. Teknologi adalah usaha manusia untuk menggunakan ilmu pengetahuan untuk kepentingan dan kesejahteraan.

Penguasaan teknologi informasi dan komunikasi (TIK) merupakan keniscayaan dalam menghadapi era globalisasi. Di era digital seperti sekarang ini, manusia dituntut untuk bisa mengoperasikan komputer seperti laptop, CPU komputer, smartphone, dan lain sejenisnya. Pengetahuan tentang teknologi informasi dan komunikasi berbasis komputer saat ini sangat dibutuhkan oleh masyarakat, baik orang dewasa maupun remaja atau anakanak yang saat ini berstatus pelajar. 
Teknologi komputerisasi saat ini sudah menjadi kebutuhan bagi setiap instansi, baik swasta maupun pemerintah.

Program Microsoft Word merupakan program pengolah kata sehingga pembuatan dokumen yang berhubungan dengan kata akan lebih maksimal jika dilakukan disini. Program ini pertama kali diperkenalkan pada tahun 1983, pada saat diperkenalkan program ini merupakan program yang dikenal dengan Multi Tool World dan digunakan untuk Xenix. Aplikasi Microsoft Office Word dapat mempermudah dalam membuat surat, laporan, makalah, artikel, tabel, skripsi dan lainnya.

Dengan terselenggaranya bidang Iptek maka peserta KKN DR-31 UINSU angkatan tahun 2021 membantu mahasiswa di Desa Kota Datar diantaranya :

\section{Sosialisasi Teknologi}

Pelaksanaan Program Sosialisasi Teknologi dilaksanakan pada hari Sabtu, 31 Juli 2021 bertempat di salah satu sekolah di Desa Kota Datar, Hamparan Perak, Deli Serdang. Kegiatannya adalah:

1. Pengenalan Ms.word dan Ms. power point

Microsoft Word atau yang akrab disebut Word merupakan salah satu produk Microsoft yang tergabung dalam Microsoft Office. Microsoft Word adalah perangkat lunak atau aplikasi pengolah kata.

Microsoft Power Point adalah program presentasi yang dikembangkan oleh Microsoft. Power Point disertakan dalam suite Microsoft Office standar bersama dengan Microsoft Word dan Microsoft Excel. Aplikasi Microsoft Word dan Microsoft Power Point memberikan kemudahan bagi mahasiswa dalam menyelesaikan tugas. Microsoft Word juga dapat dihubungkan dengan aplikasi Microsoft lainnya seperti Power Point, One Note, Outlook. Kelebihan yang dimiliki Microsoft Word membantu mempersingkat waktu dalam mengerjakan tugas. Keuntungan lain dari Microsoft Word adalah membantu meningkatkan penulisan pada dokumen.

Kegiatan ini bertujuan untuk memberikan pendampingan kepada siswa di salah satu sekolah desa di Kota Datar, Hamparan Perak, Deli Serdang dalam mengaplikasikan Microsoft Word dan Microsoft Power Point. Dengan adanya kegiatan ini diharapkan dapat mempermudah siswa dalam melakukan pengolah kata dan membuat media presentasi yang bermanfaat untuk mempermudah proses pembelajaran.

Kegiatan pelatihan Microsoft Office ini di ikuti oleh siswa yang semuanya merupakan siswa dari salah satu sekolah desa di Kota Datar, Hamparan Perak, Deli Serdang. Pelatihan ini diawali dengan sesi perkenalan antara pemateri dan mahasiswa serta penyampaian tujuannya. Selain itu, pada pertemuan ini mahasiswa juga diberikan motivasi tentang pentingnya memiliki wawasan dan pengetahuan tentang teknologi dan komunikasi. Selanjutnya siswa diberikan teori tentang Microsoft Word. Materi yang disampaikan adalah tampilan, menu dan fungsi dari ikonikon yang ada di Microsoft Word serta cara penggunaannya. Setelah siswa memahami materi tentang Microsoft Word dan cara menggunakannya, mereka diberikan latihan cara membuat tulisan dengan berbagai variasi, menyisipkan gambar, membuat daftar isi yang praktis dan manual, membuat penomoran pada kertas, serta cara membuat daftar pustaka tentang penulisan ilmiah dan menyimpan dokumen. Kemudian siswa diberikan teori serta cara menggunakan Microsoft PowerPoint. Kegiatan praktikum ini adalah membuat slide presentasi yang sederhana dan menarik dengan memanfaatkan menu-menu yang ada pada aplikasi, seperti cara menggunakan desain menu, transisi, dan animasi. 
Presentasi PowerPoint dapat terdiri dari teks, grafik, objek gambar, clipart, film, suara, dan objek yang dibuat oleh program lain.

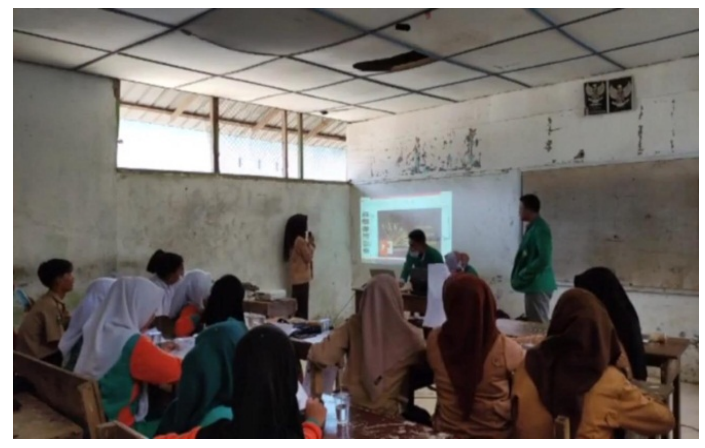

Gambar 10. Penyampaian materi Microsoft Word dan Microsoft Power Point.

\section{Simpulan}

Kuliah Kerja Nyata yang dilaksanakan saat pandemi covid-19 seperti ini berbeda dengan KKN pada umumnya. Akan tetapi semua program kerja yang disusun oleh kelompok 31 di Desa Kota Datar terlaksana dengan lancar. Kegiatan social masyarakat kelompok KKN DR-31 membantu masyarakat setempat yaitu kegiatan gotong-royong dan juga sosialisasi ke masyarakat. Kegiatan keagamaan KKN DR-31 mengikuti kegiatan Wirid Jumat dan juga mengajar dan pembinaan anak berbasis Islam. KKN-DR juga melaksanakan perlombaan dalam rangka menyambut 1 Muharram dengan tujuan utuk menunjang bakat dan minat anak-anak desa Kota Datar. Pada tema Kesehatan Masyarakat KKN DR kelompok 31 melakukan sosialisasi ke Posyandu Desa Kota Datar dan juga membagikan masker kepada warga sekitar. Selain itu kelompok 31 melaksanakan kegiatan sosialisasi teknologi dengan pengenalan Ms. Word dan Ms. Power Point kepada Siswa SMA.

\section{Daftar Pustaka}

[1] Afifah N, Abidin Z. (2020). Peran Posyandu dalam Meningkatkan Kualitas Kesehatan Ibu dan Anak di Desa
Sukawening, kabupaten Bogor. Jurnal Pusat Inovasi masyarakat . 2 (5) : 897 900.

[2] Dwi Iriani Margayaningsih. Pemberdayaan Masyarakat Desa Sebagai Upaya Penanggulangan Kemiskinan.

[3] Fitri Anasari, Addy Suyatno, Indah Fitri Astuti. (2015). Sistem Pelaporan Terpadu Kuliah Kerja Nyata Berbasis Digital (STUDI KASUS: Lembaga Pengabdian Kepada Masyarakat Universitas Mulawarman). Universitas Mulawarman.

[4] FR Amir, dkk. (2017). Community Empowerment Through Education, Religion, Social, Economic, and Health. Vol. 3 April, Bogor: Universitas Djuanda.

[5] Iswandi. (2019). Penguatan Nilai Keagamaan Bagi Kelompok Pengajian Remaja Di Kelurahan Tanah Sirah Piai XX. Jurnal Ilmiah Sosial Keagamaan,(3). 2.

[6] Kemenkes RI. (2013). Riset Kesehatan Dasar (Riskesdas) 2013. Badan Penelitian dan Pengembangan Kemenkes RI. Jakarta.

[7] Kurniawan, S. (2014). Masjid Dalam Lintasan Sejarah Umat Islam. Jurnal Khaltulistiwa,(4). 2

[8] Munawar Noor. (2011). Pemberdayaan Masyarakat.

[9] Purnomo, C. H. (2011). Panduan belajar Otodidak Microsoft Office Word 2010. Mediakita. Jakarta.

[10] Ratnawati. (2016). Memahami Perkembangan Jiwa Keagamaan Pada Anak dan Remaja. Jurnal Kajian Keislman dan Kemasyarakatan, (1). 1.

[11] Rerung R, Pahmi S, Suryana A . (2021). Pemberdayaan Potensi Masyarakat di bidang sosial, pendidikan dan teknologi dalam meningkatkan sumber daya manusia di desa margaluyu. Jurnal 
Pengabdian Kepada Masyarakat Abdi Putra. 1(1) : 6-8.

[12] Rintho Rante Rerung, dkk. (2021). Pemberdayaan Potensi Masyarakat di Bidang Sosial, Pendidikan, dan Teknologi dalam Meningkatkan Sumber Daya Manusia di Desa Margaluyu. Vol. 1 Mei, Universitas Pradita.

[13] Sarinah I, Anwar A, Suwarlan E. (2019). Pemberdayaan Masyarakat Dalam Bidang Ekonomi oleh Pemerintah desa pangandaran kecamatan pangandaran . Jurnal Moderat. 5(3) :271-277.
[14] Syardiansah. (2017). Peranan Kuliah Kerja Nyata Sebagai Bagian Dari Pengembangan Kompetensi Mahasiswa (Studi Kasus Mahasiswa Universitas Samudra KKN Tahun 2017). Universitas Samudra Aceh.

[15] Tadjuddin Noer. (2013). Budaya Gotong-Royong Masyarakat dalam Perubahan Sosial Saat Ini.Vol. 2 Mei, Yogyakarta: UGM.

[16] Wijaya, M. (2020). Kelebihan dan Kekurangan Microsoft Word. nitrotekno.com. 